\title{
Molecular confirmation of Fasciola hepatica infection in capybaras (Hydrochoerus hydrochaeris) from the state of Espírito Santo, Brazil
}

\author{
Confirmação molecular de infecção por Fasciola hepatica em capivaras \\ (Hydrochoerus hydrochaeris) do Estado do Espírito Santo, Brasil \\ Isabella Vilhena Freire Martins* (1); Giuliano Failla; Marcela Santos Sena Martins'; Gabriel José Silva Uzai; \\ Marcus Vinicius Gonçalves Viana'; Moara Cuzzuol Gomes; Guilherme Gomes Verocai² \\ ${ }^{1}$ Laboratório de Parasitologia, Departamento de Medicina Veterinária, Centro de Ciências Agrárias e Engenharias, Universidade \\ Federal do Espírito Santo - UFES, Alegre, ES, Brasil \\ ${ }^{2}$ Department of Veterinary Pathobiology, College of Veterinary Medicine and Biomedical Sciences, Texas A\&M University, College \\ Station, TX, USA
}

How to cite: Martins IVF, Failla G, Martins MSS, Uzai GJS, Viana MVG, Gomes MC, et al. Molecular confirmation of Fasciola hepatica infection in capybaras (Hydrochoerus hydrochaeris) from the state of Espírito Santo, Brazil. Braz J Vet Parasitol 2021; 30 (2): e000221. https://doi.org/10.1590/S1984-29612021027

\begin{abstract}
Sixty-two fecal samples of capybara (Hydrochoerus hydrochaeris) living in eight conservation units (CUs) across the state of Espírito Santo, southeastern Brazil, were assessed for the presence of eggs of liver flukes via sedimentation. Fasciola hepatica eggs were found in $37.1 \%$ (23/62) of the samples. Positive samples were found in six CUs (75\%), three CUs located in the southern region of the state and three others in the metropolitan region of the capital city of Vitória. Identification of Fasciola hepatica eggs collected from capybara fecal samples were based on morphology, and confirmed using molecular methods. Our results suggest that capybaras may serve as a wild reservoir host for $F$. hepatica, possibly contributing to the epidemiology and geographic range expansion of this zoonotic parasite across its vast range of distribution in South America.
\end{abstract}

Keywords: Epidemiology, fascioliasis, rodents, zoonosis.

\section{Resumo}

Sessenta e duas amostras fecais de capivaras (Hydrochoerus hydrochaeris), coletadas em oito unidades de conservação (UCs) no estado do Espírito Santo, Brasil, foram avaliadas quanto à presença de ovos de Fasciola hepatica por método de sedimentação. Ovos foram encontrados em 37,1\% (23/62) das amostras, abrangendo seis UCs (75\%), três UCs, localizadas na região sul do Estado, e outras três na região metropolitana da capital Vitória. A identificação dos ovos de $F$. hepatica coletados nas amostras fecais foi baseada na morfologia e confirmada por métodos moleculares. Os resultados sugerem que as capivaras podem servir como hospedeiros reservatórios selvagens para $F$. hepatica, possivelmente contribuindo para a epidemiologia e a expansão geográfica deste parasito zoonótico em sua vasta distribuição na América do Sul.

Palavras-chave: Epidemiologia, fasciolose, roedores, zoonose. 
The common liver fluke, Fasciola hepatica, is a digenean trematode of worldwide occurrence (Howell \& Williams, 2020). Domestic livestock, in special cattle and small ruminants, are among the most affected hosts, and infection cause a significant economic impact due to subclinical impacts, acute or chronic clinical disease, mortality, and liver condemnation at slaughter house (Howell \& Williams, 2020). Non-ruminant domestic livestock (e.g., pigs, camelids), wildlife, and human may also serve as definitive hosts for $F$. hepatica (Arias et al., 2013). Human fascioliasis is a zoonotic disease endemic to various parts of Latin America and other continents, and it is considered a neglected tropical disease by the World Health Organization (Mas-Coma et al., 2018).

Various wildlife species may serve as reservoir for F. hepatica in endemic areas of South America. In Brazil, capybaras (Hydrochoerus hydrochaeris Linnaeus, 1766) have been proven susceptible to infection by F. hepatica, and may play an important epidemiological role for this parasite (Santarém et al., 2006; El-Kouba et al., 2008; Bellato et al., 2009; Dracz et al., 2016). Reports of natural infection by F. hepatica in capybaras are common in the southern states of Brazil, where fascioliasis is endemic (El-Kouba et al., 2008; Bellato et al., 2009). However, there have been recent reports of $F$. hepatica infecting capybaras in states of southeastern Brazil, including cases of mortality (Dracz et al., 2016; Labruna et al., 2018).

Capybaras are semi-aquatic, herbivores rodents and are the world's largest rodent species. These rodents have a widespread distribution across the Neotropical region, comprising most South American countries (Reid, 2016). Across Brazil, capybaras are commonly found sharing pasture areas with domestic ruminants, and therefore prone to share potential pathogens (Labruna et al., 2018). With the expansion of urban areas, interactions between human populations and domestic and wild animals are increasing, which provides favorable situations for dissemination of diseases and pathogens between hosts and environments (El-Kouba et al., 2008).

Considering the susceptibility of capybaras to this fluke, the objective of the present study was to assess the presence of $F$. hepatica in capybaras at conservation units located (CUs) in the State of Espírito Santo, southeastern Brazil, by means of classical and molecular techniques.

This study was conducted under Research Activity Authorization number 003-2015, issued by the State Institute of the Environment (Instituto Estadual de Meio Ambiente, IEMA) and Authorization for Activities with Scientific Purposes number 47914-1 of 2015, issued by the Chico Mendes Institute for Biodiversity Conservation (ICM-Bio).

Eleven conservation units (CUs) in the state of Espírito Santo, southeastern Brazil, were visited and assessed for the presence of fecal samples of capybaras. Normally, eight hours of a single day were spent at each CU, areas at the margin of water bodies were assessed by foot by up to six trained people. These units were the following: Biological Station of Santa Lucia (EBSL), Itaúnas State Park (PEI), Pedra Azul State Park (PEPAZ), Forno Grande State Park (PEFG), Cachoeira da Fumaça State Park (PECF), Paulo César Vinha State Park (PEPCV), Mata das Flores State Park (PEMF), Environmental Protection Area of Setiba (APAS), Duas Bocas Biological Reserve (RBDB), Biological Reserve of Sooretama (RBS) and Caparaó National Park (PNC) (Figure 1).

During the period from April to July 2015, fecal samples morphologically consistent with that of capybaras were collected from the environment and were kept refrigerated. Subsequently, samples were taken for processing to the Parasitology Laboratory of the Veterinary Hospital, Federal University of the State of Espírito Santo.

The fecal samples were processed for detection of $F$. hepatica eggs using a simple sedimentation technique validated by Martins et al. (2008). The eggs were collected and observed under a compound microscope (Olympus CX41RF) at 100x magnification. Photomicrographs were captured and eggs were measured using the Dino-Eye ${ }^{\circledR}$ system and the Dino Capture ${ }^{\circledR}$ image analysis software.

Descriptive data analysis was performed, with estimation of infection frequency, considering the total number of processed samples. Mapping of location of each CU, was performed using the Quantum GIS software 2.0.

Genomic DNA was isolated from eggs isolated via fecal sedimentation and fixed in molecular-grade 96-99\% ethanol, using the DNeasy Blood \& Tissue kit (QIAGEN, Hilden, Germany), following the manufacturer's instructions. The internal transcribed spacers, including the 5.8S ribosomal unit (ITS1-5.8S-ITS2), were amplified using the forward primer BD1 (5-GTC GTA ACA ACG TTT CCG TA-3) and the reverse primer BD2 [5-TAT GCT TAA (G/A) TT CAG CGG GT-3], as previously used by Luton et al. (1992). The PCR reaction components (in a total volume of $25 \mu \mathrm{L}$ ) consisted of $2.5 \mu \mathrm{L}$ of $10 \times$ PCR buffer minus $\mathrm{Mg}$, $1.5 \mu \mathrm{L}$ of $\mathrm{MgCl}_{2}(50 \mathrm{mM}), 2 \mu \mathrm{L}$ of each dNTP $(2.5 \mathrm{mM}), 1.25 \mu \mathrm{L}$ of each oligonucleotide primer $(10 \mathrm{mM}), 0.2 \mu \mathrm{L}$ of Platinum Taq DNA polymerase $(5 \mathrm{U} / \mu \mathrm{L})$ (Invitrogen, Carlsbad, California), $13.8 \mu \mathrm{L}$ of $\mathrm{H}_{2} \mathrm{O}$, and $2.5 \mu \mathrm{L}$ of genomic DNA. The PCR thermocycling protocol consisted of $94^{\circ} \mathrm{C}$ for 3 min followed by 30 cycles of $94^{\circ} \mathrm{C}$ for $30 \mathrm{~s}, 50^{\circ} \mathrm{C}$ for $30 \mathrm{~s}$ and $72{ }^{\circ} \mathrm{C}$ for $1 \mathrm{~min}$, and then a final elongation step at $72{ }^{\circ} \mathrm{C}$ for $10 \mathrm{~min}$. 


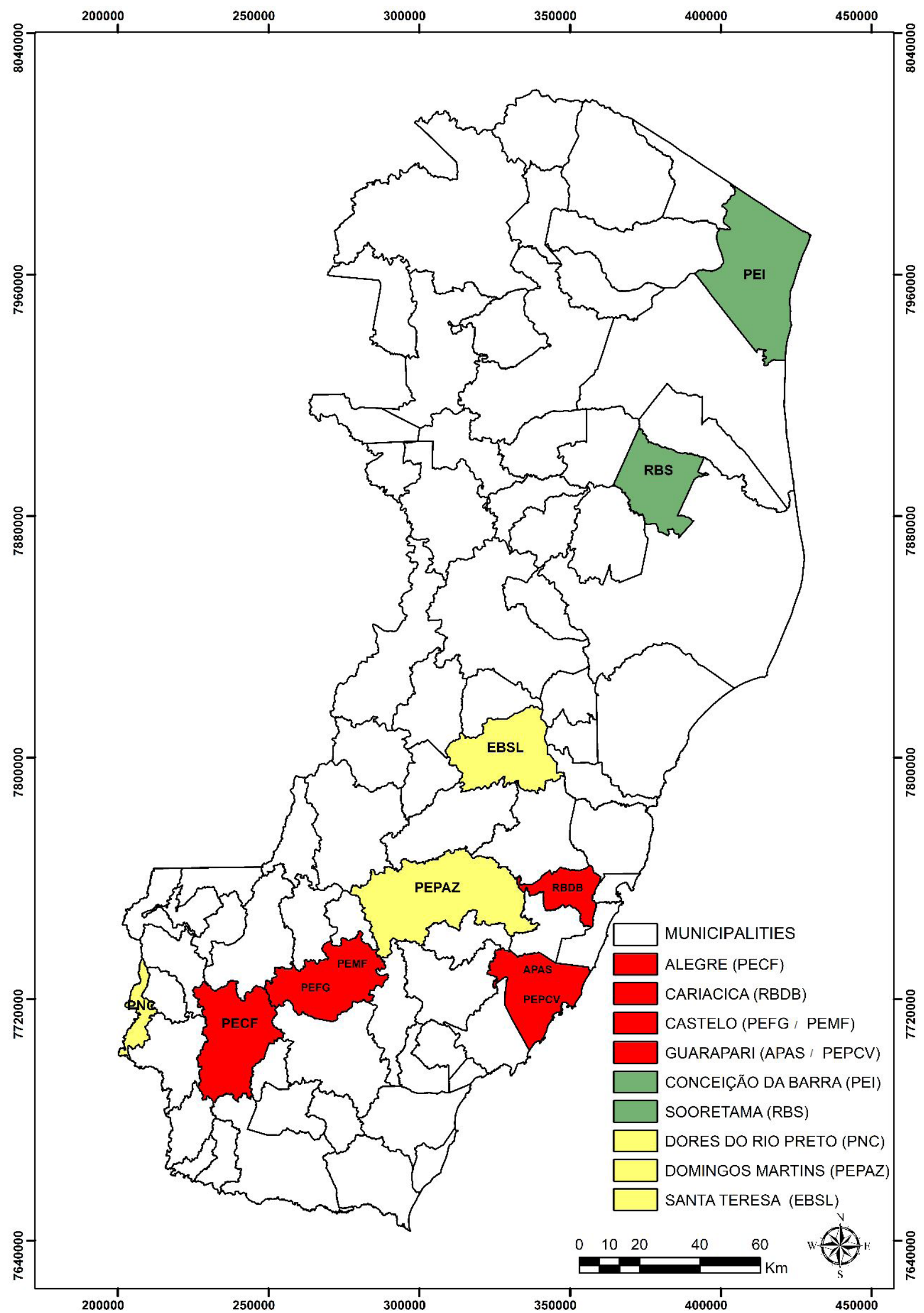

Figure 1. Geographic distribution of Fasciola hepatica eggs in fecal samples of capybaras (Hydrochoerus hydrochaeris), according to municipalities in the state of Espírito Santo, southeasthern Brazil. Municipalities where samples tested positive are marked in red; where samples tested negative, in green; and where no fecal samples were found, in yellow. 
The $28 \mathrm{~S}$ region of the rDNA was amplified using the primers digl2 (5-AAG CAT ATC ACT AAG CGG-3) and L0 [5-GCT ATC CTG AG (A/G) GAA ACT TCG-3] (Tkach et al., 2000). PCR reactions were conducted as described above and PCR cycling parameters for amplification were performed as described by Tkach et al. (2000).

The cytochrome $c$ oxidase subunit 1 (cox1) region of the mtDNA was amplified using the primers JB3 (5-TTTTTTGGGCATCCTGAGGTTTAT-3) and JB4 (5-TAAAGAAAGAACATAAGTAAAATG-3) (Bowles et al., 1995). The PCR reactions $(25 \mu \mathrm{L})$ consisted of $2.5 \mu \mathrm{L}$ of $10 \times$ PCR buffer minus $\mathrm{Mg}, 1.5 \mu \mathrm{L}$ of $\mathrm{MgCl}_{2}(50 \mathrm{mM}), 1.5 \mu \mathrm{L}$ of each dNTP $(2.5 \mathrm{mM}), 1.5 \mu \mathrm{L}$ of each oligonucleotide primer $(10 \mathrm{mM}), 0.25 \mu \mathrm{L}$ of Platinum Taq DNA polymerase $(5 \mathrm{U} / \mu \mathrm{L})$, $14.25 \mu \mathrm{L}$ of $\mathrm{H}_{2} \mathrm{O}$ and $2 \mu \mathrm{L}$ of genomic DNA. The PCR cycling parameters for amplification were the same as those used by Utuk \& Piskin (2012).

The PCR products were purified through an enzymatic treatment with ExoProStar ${ }^{\mathrm{TM}}$ (GE Healthcare) and sent for sequencing at ACTGene (Ludwig Biotec, Rio Grande do Sul, Brazil), using the same PCR primers. Subsequently, the sequences were analyzed in MEGA X (Kumar et al., 2018) and compared with other sequences available from GenBank via BLAST.

Among the 11 CUs visited, sampling for capybara feces was found in eight of them. A total of 62 samples were collected and the presence of large, golden-brown operculated eggs, characteristic of $F$. hepatica were found in $37.1 \%$ (23/62) of the samples. The mean length and width of $F$. hepatica eggs were $118.49 \mu \mathrm{m}$ and $64.65 \mu \mathrm{m}$, respectively. Positive samples were present in six CUs (75\%) with frequency ranging from 28.57 to $85.71 \%$ (Table 1).

Table 1. Frequency of Fasciola hepatica eggs in fecal samples from capybaras (Hydrochoerus hydrochaeris) in conservation units in the state of Espírito Santo, southeastern Brazil, diagnosed using simple fecal sedimentation, from April to July 2015.

\begin{tabular}{|c|c|c|c|c|}
\hline \multirow{2}{*}{$\begin{array}{c}\text { Conservation unit, Espírito Santo, } \\
\text { Brazil }\end{array}$} & \multicolumn{2}{|c|}{ Geographic coordinates } & \multirow{2}{*}{$\begin{array}{l}\text { Number of } \\
\text { samples }\end{array}$} & \multirow{2}{*}{$\begin{array}{l}\text { Positive for } \\
\text { F. hepatica eggs }\end{array}$} \\
\hline & Latitude & Longitude & & \\
\hline Santa Lúcia Biological Station & S 19057'12" & W 40³1'13" & 0 & - \\
\hline Itaúnas State Park & $\mathrm{S} 18^{\circ} 25^{\prime} 5.97^{\prime \prime}$ & W $39^{\circ} 42^{\prime} 25.68^{\prime \prime}$ & 4 & 0 \\
\hline Pedra Azul State Park & $\mathrm{S} 20^{\circ} 23^{\prime} 57.72^{\prime \prime}$ & $W 41^{\circ} 1^{\prime} 28.84^{\prime \prime}$ & 0 & - \\
\hline Forno Grande State Park & S 2031'13" & W $41^{\circ} 6^{\prime} 21^{\prime \prime}$ & 4 & $2(50 \%)$ \\
\hline Cachoeira da Fumaça State Park & $\mathrm{S} 20^{\circ} 36^{\prime} 35^{\prime \prime}$ & W $41^{\circ} 36^{\prime} 26^{\prime \prime}$ & 6 & $3(50 \%)$ \\
\hline Paulo César Vinha State Park & $\mathrm{S} 20^{\circ} 32^{\prime} 44^{\prime \prime}$ & W $40^{\circ} 22^{\prime} 71^{\prime \prime}$ & 18 & $8(44.4 \%)$ \\
\hline Mata das Flores State Park & S $20^{\circ} 35^{\prime} 54^{\prime \prime}$ & W 41ำ'53" & 7 & $6(85.71 \%)$ \\
\hline Environmental Protection Area of Setiba & S $20^{\circ} 31^{\prime}, 37^{\prime \prime}$ & W $40^{\circ} 22^{\prime} 40^{\prime \prime}$ & 5 & $2(40 \%)$ \\
\hline Duas Bocas Biological Reserve & $\mathrm{S} 20^{\circ} 16^{\prime} 24^{\prime \prime}$ & W $40^{\circ} 30^{\prime} 31^{\prime \prime}$ & 7 & $2(28.57 \%)$ \\
\hline Sooretama Biological Reserve & S $19^{\circ} 3^{\prime} 24.51^{\prime \prime}$ & W $40^{\circ} 8^{\prime} 51.83^{\prime \prime}$ & 9 & 0 \\
\hline Caparaó National Park & $\mathrm{S} 20^{\circ} 25^{\prime} 18^{\prime \prime}$ & W $41^{\circ} 51^{\prime} 12^{\prime \prime}$ & 0 & - \\
\hline TOTAL & & & 62 & $23(37.1 \%)$ \\
\hline
\end{tabular}

Among the localities with positive samples (Figure 1, shown in red), three were in municipalities in the southern region of the state (Alegre and Castelo) and three were from municipalities in the metropolitan region (Guarapari and Cariacica). No eggs were observed in feces obtained from CUs in the central region (Sooretama) or north region of the state (Conceição da Barra) (shown in green). No fecal samples were obtained (shown in yellow) from CUs in Domingos Martins and Santa Teresa (central region) and Dores do Rio Preto (southern region).

Representative sequences of each amplified marker were accessioned in GenBank. The ITS sequence (908bp; MW182345) the large subunit/28S (1,240bp; MW125781), and cox1 (447bp; MW077510) were 99.1-100\%, 100\%, and $99.5-100 \%$ similar to homologous sequences of $F$. hepatica.

To our knowledge, this is the first report of $F$. hepatica infection in capybaras in the endemic region of Espírito Santo, southeastern Brazil. Only a handful of reports are known from southern states, and other states in southeastern Brazil. In a study conducted by El-Kouba et al. (2008), in three public parks in the municipality of 
Curitiba, state of Paraná, F. hepatica eggs were found with a prevalence of 54.5\% (18/33) in one of the parks, slightly higher than the overall prevalence found in our study. Bellato et al. (2009) conducted a study in the municipality of Timbó, state of Santa Catarina, Brazil, and found the prevalence of $F$. hepatica infection to be $18.12 \%$ for cattle and $8.96 \%$ for capybaras; whereas in Dracz et al. (2016), F. hepatica eggs were retrieved in only one out of 11 fecal samples of capybaras from the state of Minas Gerais. El-Kouba et al. (2008) and Dracz et al. (2016) reported mean dimensions for $F$. hepatica eggs retrieved from capybara feces of $138.56 \mu \mathrm{m}$ in length and $72.96 \mu \mathrm{m}$ in width, and $142.74 \mu \mathrm{m}$ and $75.74 \mu \mathrm{m}$, respectively. However, according to Valero et al. (2001), the morphometry of $F$. hepatica eggs is highly variable among different host species and geographic locations.

Studies in the state of have indicated that $F$. hepatica cause significant economic impact to cattle industry. A mean prevalence of $22.91 \%$ is reported based on inspection of bovine livers at slaughterhouses in the southern region of the state (Bernardo et al., 2011). A more recent study, revealed an increased frequency of $F$. hepatica in cattle (Martins et al., 2014), and infection has been reported in sheep, goat and water buffalo from the same region (Carneiro et al., 2013). Moreover, the presence of the snail intermediate host, Pseudossuccinea columella, has been confirmed in Espírito Santo, enabling the F. hepatica life cycle to be completed autochthonously in this endemic area. (Medeiros et al., 2014).

The occurrence of $F$. hepatica in capybaras from CUs in the metropolitan region corroborates the findings of Freitas et al. (2014), who observed presence of this fluke in livers at a slaughterhouse between 2009 and 2011. Furthermore, these authors proposed a bioclimatic zoning scheme for occurrences of $F$. hepatica in the state of Espírito Santo, considering factors such as altitude, air temperature, rainfall and topography, and their respective risks for potential occurrence of $F$. hepatica. They found that $52.22 \%$ of the entire territory of the state is located in areas that are favorable for occurrence of F. hepatica, including the metropolitan region of the State, an other region assessed in our study (Martins et al., 2014).

Capybaras are herbivores with strong association with aquatic habitats (Reid, 2016), which possibly increase the likelihood of infection by ingesting metacercariae of $F$. hepatica, and also of water contamination, since defecation may occur next to or inside water bodies. Capybaras and cattle are frequently found grazing in the same areas, which may suggest that $F$. hepatica can be disseminated from cattle to wildlife and vice versa, (Arias et al., 2013). In addition, capybaras are highly adaptable to many habitats, and this facilitates their establishment in urban areas subject to anthropic activity (Reid, 2016). This proximity with human populations may provide favorable conditions for the dissemination of F. hepatica (El-Kouba et al., 2008). Altogether, these factors highlight the capybara's potential as wild reservoirs of $F$. hepatica throughout their vast geographic range, which encompasses most countries in continental South America (Reid, 2016).

Zoonotic fascioliasis occurs when humans ingest metacercariae of F. hepatica along contaminated leafy greens, in special watercress. In Brazil, human fascioliasis is not a reportable disease, and therefore its prevalence is likely underestimated (Pritsch et al., 2019). While it remains unclear whether capybaras could play an important role to human infection, avoiding contamination of water sources used for irrigation with feces of susceptible hosts and fencing off areas of cultures that require an aquatic environment remain as relevant control measures.

This is the first report of capybaras naturally infected by F. hepatica in the state of Espírito Santo, southeastern Brazil. Our findings emphasize the importance of epidemiological studies in this region, with the objective of estimating and locating areas where $F$. hepatica is present in the state. Such studies may contribute towards adoption of more comprehensive control measures, covering not only domestic ruminants but also wildlife. Susceptible wildlife reservoirs may play a significant epidemiological role for this emerging, neglected zoonosis.

\section{Acknowledgements}

This study was partially funded by the Fundação de Amparo à Pesquisa e Inovação do Espírito Santo (FAPES). We would like to thank the personnel with the Instituto de Meio Ambiente e Recursos Hídricos (IEMA), who assisted with sample collections in the field.

\section{References}

Arias MS, Piñeiro P, Sánchez-Andrade R, Suárez JL, Hillyer GV, Díez-Baños P, et al. Relationship between exposure to Fasciola hepatica in roe deer (Capreolus capreolus) and cattle extensively reared in an endemic area. Res Vet Sci 2013; 95(3): 1031-1035. http://dx.doi.org/10.1016/j.rvsc.2013.07.027. PMid:23993660. 
Bellato V, Souza AP, Sartor AA, Veiga LPHN, Centenaro F. Ocorrência de Fasciola hepatica na população de capivaras (Hydrochaeris hydrochaeris) e em bovinos (Bos taurus) no município de Timbó, SC. Rev Ciênc Agrovet 2009; 8(1): 66-70.

Bernardo CC, Carneiro MB, Avelar BR, Donatele DM, Martins IVF, Pereira MJS. Prevalence of liver condemnation due to bovine fasciolosis in Southern Espírito Santo: temporal distribution and economic losses. Rev Bras Parasito/ Vet 2011; 20(1): 49-53. http:// dx.doi.org/10.1590/S1984-29612011000100010. PMid:21439232.

Bowles J, Blair D, McManus DP. A molecular phylogeny of the human schistosomes. Mol Phylogenet Evol 1995; 4(2): $103-109$. http://dx.doi.org/10.1006/mpev.1995.1011. PMid:7663756.

Carneiro MB, Alves DP, Donatele DM, Pereira OS Jr, Martins IVF. Fasciola hepatica em ovinos, caprinos e bubalinos em municípios do sul do Espírito Santo. Arq Inst Biol (Sao Paulo) 2013; 80(4): 442-446. http://dx.doi.org/10.1590/S1808-16572013000400011.

Dracz RM, Ribeiro VMA, Pereira CAJ, Lima WS. Occurrence of Fasciola hepatica (Linnaeus, 1758) in capybara (Hydrochoerus hydrochaeris) (Linnaeus, 1766) in Minas Gerais, Brazil. Rev Bras Parasitol Vet 2016; 25(3): 364-367. http://dx.doi.org/10.1590/ S1984-29612016021. PMid:27096531.

El-Kouba MMAN, Marques SMT, Pilati C, Hamann W. Aspectos gerais da fasciolose e de endoparasitoses em capivaras (Hydrochaeris hydrochaeris Linnaeus, 1766) de três parques no Paraná, Brasil. Vet Foco 2008; 6(1): 4-15.

Freitas DF, Martins IV, Dos Santos GM, Dos Santos AR, Gomes DS. Bioclimatic distribution and prevalence maps for Fasciola hepatica in Espírito Santo State, Brazil. J Venom Anim Toxins Incl Trop Dis 2014; 20: 32. http://dx.doi.org/10.1186/1678-9199-2032. PMid:25101121.

Howell AK, Williams DJL. The epidemiology and control of liver flukes in cattle and sheep. Vet Clin North Am Food Anim Pract 2020; 36(1): 109-123. http://dx.doi.org/10.1016/j.cvfa.2019.12.002. PMid:32029178.

Kumar S, Stecher G, Li M, Knyaz C, Tamura K. MEGA X: Molecular Evolutionary Genetics Analysis across computing platforms. Mol Biol Evol 2018; 35(6): 1547-1549. http://dx.doi.org/10.1093/molbev/msy096. PMid:29722887.

Labruna MB, Costa FB, Port-Carvalho M, Oliveira AS, Souza SLP, Castro MB. Lethal Fascioliasis in Capybaras (Hydrochoerus hydrochaeris) in Brazil. J Parasitol 2018; 104(2): 173-176. http://dx.doi.org/10.1645/17-114. PMid:29185852.

Luton K, Walker D, Blair D. Comparisons of ribosomal internal transcribed spacers from two congeneric species of flukes (Platyhelminthes: trematoda Digenea). Mol Biochem Parasito/ 1992; 56(2): 323-327. http://dx.doi.org/10.1016/0166-6851(92)90181-I. PMid:1484553.

Martins IV, Avelar BR, Bernardo C, Leão AC, Salim MJ. Distribution of bovine fasciolosis and associated factors in south Espírito Santo, Brazil: an update. Rev Bras Parasito/ Vet 2014; 23(1): 23-29. http://dx.doi.org/10.1590/S1984-29612014003. PMid:24728357.

Martins IV, Bernardo CC, De Avelar BR, De Araújo IB, Donatele DM, Nunes LC. Sensibilidade e reprodutibilidade da técnica de sedimentação (Foreyt, 2005) para o diagnóstico de Fasciola hepatica. Rev Bras Parasitol Vet 2008; 17(Supl. 1): $110-112$. PMid:20059828.

Mas-Coma S, Bargues MD, Valero MA. Human fascioliasis infection sources, their diversity, incidence factors, analytical methods and prevention measures. Parasitology 2018; 145(13): 1665-1699. http://dx.doi.org/10.1017/S0031182018000914. PMid:29991363.

Medeiros C, Scholte RGC, D'ávila S, Caldeira RL, Carvalho OS. Spatial distribution of Lymnaeidae (Mollusca, Basommatophora), intermediate host of Fasciola hepatica Linnaeus, 1758 (Trematoda, Digenea) in Brazil. Rev Inst Med Trop São Paulo 2014; 56(3): 235-252. http://dx.doi.org/10.1590/S0036-46652014000300010. PMid:24879003.

Pritsch IC, Garcia RL, Douat D, Schwendler RR, Buttendorf MRB, Molento MB. First reported case of clinical fascioliasis in Santa Catarina, Brazil. Rev Soc Bras Med Trop 2019; 52: e20190070. http://dx.doi.org/10.1590/0037-8682-0070-2019. PMid:31340366.

Reid F. Hydrochoerus hydrochaeris. The IUCN Red List of Threatened Species [online]. 2016 [cited 2021 Mar 10]. Available from: https://www.iucnredlist.org/species/10300/22190005

Santarém VA, Tostes RA, Alberti H, Sanches OC. Fasciola hepatica in capybara. Acta Trop 2006; 98(3): 311-313. http://dx.doi. org/10.1016/j.actatropica.2006.05.004. PMid:16774732.

Tkach V, Pawlowski J, Mariaux J. Phylogenetic analysis of the suborder Plagiorchiata (Platyhelminthes, Digenea) based on partial IsrDNA sequences. Int J Parasitol 2000; 30(1): 83-93. http://dx.doi.org/10.1016/S0020-7519(99)00163-0. PMid:10675749.

Utuk AE, Piskin FC. Molecular detection and characterization of goat isolate of Taenia hydatigena in Turkey. ScientificWorldJournal 2012; 2012: 962732. http://dx.doi.org/10.1100/2012/962732. PMid:22500144.

Valero MA, Darce NA, Panova M, Mas-Coma S. Relationships between host species and morphometric patterns in Fasciola hepatica adults and eggs from the northern Bolivian Altiplano hyperendemic region. Vet Parasitol 2001; 102(1-2): 85-100. http://dx.doi. org/10.1016/S0304-4017(01)00499-X. PMid:11705655. 